\title{
The role of traditional knowledge and access to genetic resources in biodiversity conservation in Southeast Asia
}

\author{
Christoph Antons
}

Received: 16 September 2009/Accepted: 13 February 2010/Published online: 7 March 2010

(C) The Author(s) 2010. This article is published with open access at Springerlink.com

\begin{abstract}
The article examines international treaties linking trade and environment, their governance models and implementation in the context of Southeast Asia. Particular attention is being paid to the role of intellectual property concepts, customary law and traditional knowledge as incentives for biodiversity conservation and to difficulties in defining the subject matter and communities of knowledge holders. Indonesia's regulation of traditional knowledge and access to biodiversity is discussed as example. The article concludes that national development goals and interests in royalty collection frequently dominate the discussion and that key concepts are still insufficiently defined to avoid overlaps and conflicts. Genuine local support for the conservationist aims of the models will depend on whether a benefit flow to communities can be ensured and their original role to act as incentives can be realised. International collaboration is important to avoid disputes concerning biodiversity related knowledge held across borders.
\end{abstract}

Keywords Incentives for community based biodiversity conservation . Definitions of traditional knowledge - Definitions of knowledge holding communities . Access to genetic resources $\cdot$ Intellectual property rights

C. Antons $(\square)$

Faculty of Law and Centre for Comparative Law and Development Studies in Asia and the Pacific (CLDSAP), Centre for Asia-Pacific Social Transformation Studies (CAPSTRANS),

University of Wollongong, NSW 2522, Australia

e-mail: cantons@uow.edu.au

C. Antons

ARC Centre of Excellence for Creative Industries and Innovation (CCI),

Queensland University of Technology, Kelvin Grove, Australia

C. Antons

Max Planck Institute for Intellectual Property, Competition and Tax Law, Munich, Germany 


\section{Introduction: biodiversity protection in Southeast Asia}

Over the past few years, there has been an increasingly lively debate about local governance related to the environment in the countries of Southeast Asia, to counter deforestation and the unsustainable exploitation of the region's natural environment. Several factors have become important in triggering such debates. First, although the processes are as yet uneven and contested, many countries have experienced democratisation processes, which have given more opportunities to NGOs and communities at the grassroots level to voice their concerns and their grievances (Asia Sentinel 2009). Second, in some countries attempts at political and administrative decentralisation have been undertaken aiming at greater autonomy and authority for local decision makers (von Benda-Beckmann and von Benda-Beckmann 2007) and at a replacement of "top down" with "bottom up" governance models. Third, agricultural output, long taken for granted, is of renewed importance to national development planners after several countries experienced a food crisis and worrying price rises in 2007 and early 2008 (Burnett 2009; Wheatley 2008). Fourth, climate change and its potentially devastating impact on developing countries have entered the agenda. Fifth and finally, from a legal perspective, a number of important international treaties linking trade and environmental issues were concluded during the 1990s (Tay and Esty 1996) and they are now entering the implementation stage or are under discussions for further amendments.

In this article, I will examine some of these treaties and the environmental governance and biodiversity protection models they propose, whereby I will focus on the role of intellectual property concepts in promoting traditional knowledge about biodiversity. Several contributions in this volume have stressed the importance of alternative sustenance opportunities and of financial incentives for conservation endeavours to be successful (Sodhi et al. 2009; Wilcove and Koh 2010). One of the approaches to create such incentives has been the idea to combine some of the most advanced forms of intellectual property with some of the oldest forms of knowledge in attempts to implement the provisions of the Convention on Biological Diversity and of other treaties discussed below. The article will examine these attempts at creating intellectual property based incentives, the important role reserved in such schemes for communities of forest dwellers and farmers as knowledge holders and the difficulties in establishing their membership and territorial boundaries. The argument will be made that the different categories of traditional knowledge and of knowledge holders have remained vaguely defined, which leads to overlap in the various laws that provide protection and to local, regional and international conflicts. Further, national governments continue to play substantial roles in implementing benefit sharing schemes. It will be argued that these benefits must be passed on to the knowledge holding communities, if they are meant to become real stakeholders in such "bottom up" environmental governance schemes. Further, to have real effects for biodiversity protection, intellectual property based rights to traditional knowledge should not lose sight of the broader aims of the Convention on Biological Diversity and not become mere instruments used at the central administrative level for royalty collection and opposition to patenting of local knowledge abroad, as important as these tasks may be. The article will use various examples from Southeast Asia with a particular focus on Indonesia to discuss the experiences thus far in linking traditional knowledge and biodiversity protection. 


\section{International treaties for the protection of biodiversity}

Access to genetic resources and related traditional knowledge, the topic of this article, has been regulated in and is affected by several international agreements. The most important are the Convention on Biological Diversity (CBD) concluded in 1992, the WTO Agreement on Trade-Related Aspects of Intellectual Property Rights (TRIPS) of 1994 and the International Treaty on Plant Genetic Resources for Food and Agriculture (ITPGR) negotiated under the auspices of the Food and Agriculture Organization (FAO). Currently under discussion are further international framework provisions dealing with animal genetic resources and marine genetic resources (WIPO 2008, pp. 19-20). Perhaps most important for the current paradigms for national and local governance related to genetic resources and traditional knowledge are several provisions of the CBD. The link between trade and commercial exploitation, on the one hand, and conservation and protection, on the other hand, is explicitly made in Article 1 that lists as objectives of the CBD "the conservation of biological diversity, the sustainable use of its components and the fair and equitable sharing of the benefits arising out of the utilization of genetic resources, including by appropriate access to genetic resources and by appropriate transfer of relevant technologies, taking into account all rights over those resources and to technologies, and by appropriate funding." Article 3 CBD provides that "States have, in accordance with the Charter of the United Nations and the principles of international law, the sovereign right to exploit their own resources pursuant to their environmental policies, and the responsibility to ensure that activities within their jurisdiction and control do not cause damage to the environment of other States or of areas beyond the limits of national jurisdiction.' The focus of many analysts has been on the first part of this provision, because it appears as a significant departure from the previous understanding of plant genetic resources (PGR) as 'heritage of mankind' that is freely accessible and exchangeable, a principle that was still included in the non-binding International Undertaking on Plant Genetic Resources of 1983. ${ }^{1}$ Flitner (1998, pp. 153-154) explains that already during the discussion of this principle in FAO, mainly developed country members of the International Union for the Protection of New Varieties of Plants (UPOV), but also some developing countries expressed reservations about the continuing perception of genetic resources as 'heritage of mankind'. Brush (2005, pp. 77-78) points out how the change of paradigm in the early 1990s was influenced by neo-liberal policies in international development (see also Murray Li 2007, p. 232; Newell 2008), ideas about more participatory and non-governmental programs and by claims about "biopiracy" stemming from imbalances between strong intellectual property rights and weak public benefits for traditional farmers and local holders of knowledge about biodiversity.

The CBD foresees an exchange relationship between resource providers and users. Resource providing countries shall "endeavour to create conditions to facilitate access to genetic resources for environmentally sound uses by other Contracting Parties and not to impose conditions that run counter to the objectives of this Convention" (Article 15.2. CBD). Resource using convention parties shall take measures to develop and carry out scientific research "with the full participation of, and where possible in" the resource providing party (Article 15.6. CBD); and share "in a fair and equitable way the results of research and development and the benefits arising from the commercial and other utilization" with the resource providing party (Article 15.7. CBD). Resource users shall

1 The International Undertaking is an Annex to FAO Resolution 8/83, taken at the 22nd Session of the FAO Conference, Rome, 5-23 November 1983. 
provide access to and transfer of technology to resource providing countries (Article 16.3. CBD), in particular to government institutions and the private sector of developing countries (Article 16.4. CBD). There are further provisions for technical and scientific cooperation (Article $18 \mathrm{CBD}$ ), participation of resource providers in biotechnological research and access to the results and benefits from biotechnologies based upon use of the provided genetic resources (Article $19 \mathrm{CBD}$ ).

Article 15.1 CBD confirms the sovereign rights of States over their natural resources and clarifies that "the authority to determine access to genetic resources rests with the governments and is subject to national legislation." However, while most of the exchange of resources and benefits is framed as a relationship between state parties, "indigenous and local communities embodying traditional lifestyles relevant for the conservation and use of biological diversity" become relevant in Article 8 (j) CBD. The provision requires from state parties to "respect, preserve and maintain knowledge, innovations and practices" of such communities and to "promote their wider application with the approval and involvement of the holders of such knowledge, innovations and practices and encourage the equitable sharing of benefits arising from the utilization of such knowledge, innovations and practices". The obligations for a national government to protect such traditional knowledge arise, however, "subject to its national legislation". In line with the utilitarian view of biodiversity conservation, Article 11 CBD foresees further that governments shall "as far as possible and as appropriate, adopt economically and socially sound measures that act as incentives for the conservation and sustainable use of components of biological diversity". "Incentives" has been interpreted as including not only economic but also social and legal measures (Biber-Klemm and Szymura Berglas 2006, pp. 31-34). This in turn may include property right mechanisms such as the granting of intellectual property rights to holders of traditional knowledge (Newell 2008, p. 85).

The International Treaty on Plant Genetic Resources for Food and Agriculture (ITPGR), negotiated under the auspices of FAO in 2001 and in force since 2004, aims at playing a similar role as the CBD for agricultural biodiversity. Its objectives are "the conservation and sustainable use of plant genetic resources for food and agriculture and the fair and equitable sharing of the benefits arising out of their use, in harmony with the Convention on Biological Diversity, for sustainable agriculture and food security" (Article 1.1). According to the preamble it sees questions regarding the management of plant genetic resources for food and agriculture as being "at the meeting point between agriculture, the environment and commerce" and it aims to promote "synergy among these sectors". Similarly as the CBD, the ITPGR establishes a special role for farmers, indigenous and local communities. It requires from parties to "promote or support, as appropriate, farmers and local communities' efforts to manage and conserve on-farm their plant genetic resources for food and agriculture" (Article 5.1 (c)); and "to promote in situ conservation of wild crop relatives and wild plants for food production, including in protected areas, by supporting, inter alia, the efforts of indigenous and local communities" (Article 5.1 (d)).

\section{Intellectual property rights in the CBD and in TRIPS}

The CBD recognises and respects intellectual property rights (Article 16.2. CBD), but foresees in Article 16.5. that contracting parties "shall cooperate in this regard subject to national legislation and international law in order to ensure that such rights are supportive of and do not run counter to its objectives." This provision has led to a debate between WTO member states whether a revision of the WTO TRIPS Agreement is required to bring 
the agreement into line with the CBD in particular as far as the protection of traditional knowledge of local and indigenous communities mentioned in Article 8 (j) CBD is concerned. The TRIPS Agreement does not make reference to traditional knowledge. It does, however, require the granting of intellectual property rights to plant varieties, either in the form of patents or "by an effective sui generis system or by any combination thereof" (Article 27.3 (b) TRIPS). As for patents, the same provision of Article 27.3 (b) TRIPS allows for the exclusion from patentability of "plants and animals other than micro-organisms, and essentially biological processes for the production of plants or animals other than nonbiological and micro-biological processes". The provision aims at a fundamental distinction in patent law between non-patentable discoveries and inventions, which may be patented. The TRIPS Agreement leaves it to national legislation where precisely to set the threshold (Gervais 2003, p. 229). However, with the growth of the biotechnology industry, patenting of micro-organisms has become common following the decision of the US Supreme Court in Diamond v Chakrabarty (Rimmer 2008, pp. 24-49) and is now required in the TRIPS Agreement as is the patenting of non-biological and micro-biological processes. From its introduction, Article 27.3 (b) provided for a review of the provision four years after the date of entry into force of the WTO Agreement. While this mandate was reiterated at the Doha Ministerial Conference in 2001, the review has not generated any substantive results (BiberKlemm et al. 2006, p. 79; Gervais 2003, pp. 227-234).

In the international debate about the extension of intellectual property protection to plant varieties in particular, traditional knowledge has been used partly as a counterargument to defend regional, national and local interests especially related to food security and agriculture. It has further been used to raise counterclaims for the protection of knowledge more typically to be encountered in developing countries. The focus of this discussion has recently been on the proposal of a group of developing countries to require the disclosure in patent applications of the origin of any resources and/or associated knowledge used in generating an invention as well as evidence of prior informed consent and equitable benefit-sharing, a proposal which in turn triggered alternative proposals from the US, Japan, the EU and Switzerland (Straus 2008, pp. 229-231).

\section{International definitions of "traditional knowledge"}

The precise definition of traditional knowledge is equally still debated. An early manifestation in the field of agricultural knowledge is the concept of "farmers' rights" defined in two FAO Resolutions of 1989 annexed to the 1983 International Undertaking on Plant Genetic Resources as

rights arising from the past, present and future contribution of farmers in conserving, improving and making available Plant Genetic Resources, particularly those in the centres of origin/diversity. These rights are vested in the International Community, as trustees for present and future generations of farmers, for the purposes of ensuring full benefits of farmers and supporting the continuation of their contributions (as cited in Correa 2000, p. 4).

These rights have now also entered the ITPGR, which speaks in Article 9.1 of

the enormous contribution that the local and indigenous communities and farmers of all regions of the world, particularly those in the centres of origin and crop diversity, have made and will continue to make for the conservation and development of plant 
genetic resources which constitute the basis of food and agriculture production throughout the world.

Article 9.2 ITPGR foresees that national governments should "as appropriate, and subject to national legislation" promote farmers' rights by protecting traditional knowledge, granting the right to equitable benefit-sharing and the right to participate in decisionmaking at the national level with regards to the conservation and sustainable use of plant genetic resources for food and agriculture.

To tackle the role of traditional knowledge related intellectual property rights, the World Intellectual Property Organization in 2000 formed an Intergovernmental Committee on Intellectual Property and Genetic Resources, Traditional Knowledge and Folklore (IGC), which began its deliberations in 2001. When the WIPO IGC began its discussions of traditional knowledge, it initially used a working definition resulting from a report that was drafted after fact-finding missions conducted in 1998 and 1999 and apparently inspired by holistic explanations of the subject matter that WIPO representatives encountered during these missions (Antons 2009a, pp. 2-3). In accordance with the understanding in many indigenous communities, the initial working definition did not distinguish between traditional forms of knowledge and folkloristic expressions used to transmit the knowledge and to hand it down to the next generation (Antons 2005). Soon afterwards, however, the IGC began to distinguish between expressions of folklore or traditional cultural expressions, on the one hand, and traditional knowledge 'in the strict sense' or 'technical traditional knowledge' (WIPO 2003, 2006). In its reproduction of its document on 'The Protection of Traditional Knowledge: Revised Objectives and Principles' (WIPO 2007), WIPO defines the general scope of the subject matter in Article 3(2) as follows:

the content or substance of knowledge resulting from intellectual activity in a traditional context, and includes the know-how, skills, innovations, practices and learning that form part of traditional knowledge systems, and knowledge embodying traditional lifestyles of indigenous and local communities, or contained in codified knowledge systems passed between generations. It is not limited to any specific technical field, and may include agricultural, environmental and medicinal knowledge, and knowledge associated with genetic resources.

The role and nature of protection of traditional knowledge has remained contentious. At the final meeting before the expiration of its current mandate, the IGC was initially unable to agree on a work agenda for the biennium 2010-2011. While many developing countries were urging members to begin "text-based negotiations" for a treaty, other IGC members thought that further deliberations are necessary, as many basic questions still required further clarification (WIPO 2009a). At their Annual Assemblies at the end of 2009, WIPO member states finally renewed the IGC mandate with the objective of reaching agreement on a text of an international legal instrument (or instruments) (WIPO 2009b).

\section{Biodiversity related traditional knowledge in Southeast Asian developing countries: who are the knowledge holders?}

The IGC definition of traditional knowledge is "not limited to any specific technical field" but envisages as main forms "agricultural, environmental and medicinal knowledge, and knowledge associated with genetic resources." While these may appear as potentially different forms for the purposes of regulation and subject to the regulatory authorities of 
different ministries as well as to different forms of intellectual property rights, it has been pointed out that there is much overlap in reality. Traditional medicinal knowledge may depend on forest resources as well as on resources cultivated in herbal gardens. For example, it is said that $25 \%$ of the raw materials for the traditional Indonesian medicine jати is collected from the forests by people knowledgeable with regards to the medicinal benefits of such forest resources, but that the number of such skilled collectors is in decline and that there is a danger of unsustainable harvesting of wild plants (Antons and AntonsSutanto 2009, p. 365; Beers 2001, p. 74; Erdelen et al. 1999, p. 3). The importance of forest resources will obviously differ according to the specific environment of the various Indonesian regions. For the Indonesian main island of Java, the original home of the term јати, many resources for privately prepared traditional medicine come from the traditional family medical gardens (taman obat keluarga). Such private medical gardens are recently making a comeback and they are encouraged by the government as a cost-effective form of public health (Antons and Antons-Sutanto 2009, p. 369). Where production of jamu moves upstream and is carried out by commercial manufacturers, cooperation of the manufacturers with local farmers that cultivate the plants is also becoming increasingly common (Antons and Antons-Sutanto 2009, p. 365).

While both cultivated and naturally growing plants are thus used for the making of traditional medicine, it is equally difficult to distinguish clearly between agricultural and biodiversity related knowledge. Such a distinction becomes important where there are different laws promising benefit sharing to farming communities in the context of "farmers rights", on the hand, and to communities more generally (or to indigenous communities under laws for the protection of indigenous peoples) for biodiversity related knowledge on the other hand. In India, for example, there are such overlaps between the Protection of Plant Varieties and Farmers Rights Act and the Biological Diversity Act and they may potentially lead to repeated requests for compensation (Sagar 2005, pp. 386-387). This potential for overlaps is acknowledged in Article 5.1 (d) ITPGR, which speaks of the efforts of indigenous and local communities in conserving wild crop relatives and wild plants for food production. The lines, however, remain difficult to draw. Forsyth and Walker (2008, p. 63) in their work on Thailand, for example, explain that the previous dichotomy between lowland farmers and forest conserving tribal people in the uplands and their various forms of associated knowledge is not or no longer accurate. Both lowland farmers and hill tribe people have long begun to supplement their livelihood with income sourced from outside of their "traditional" living spaces. Hill tribe people have begun to work as agricultural labourers on lowland farms in surrounding villages. At the same time, lowland farmers are engaging in part-time supplementary swidden agriculture in the uplands, with some of them also cultivating fruit orchards and irrigated paddy fields. The authors conclude that in fact " "lowland" Thai are probably the majority in the uplands' (Forsyth and Walker 2008, pp. 60-63, 222).

It appears that an often essentialising but at the same time blurry picture of the "indigenous and local communities embodying traditional lifestyles" poses one of the fundamental problems for community focused models of environmental governance as envisaged in the CBD and in the proposals developed by international organisations such as the WIPO IGC. There are often simplifying assumptions about the homogeneity of communities, about the relatively unchanged nature of their cultures and their conservation practices and about the relatively clear delineations of the geographical space that they inhabit. Critics have argued that "despite the persistence of the commons methaphor" in the environmental governance debate often "local conditions and local cultures conveniently disappear from the view" (Goldman 1998, p. 5) and that approaches emphasising 
community based research management "increasingly rely on stereotypical symbols of cultural difference that tend to associate particular ecological niches with particular forms of culture, knowledge and identity" (Forsyth and Walker 2008, p. 63). Ignored in such essentialising representations of communities and their geographical space are the often large influxes of migrant settlers (Forsyth and Walker 2008, p. 208; von Benda-Beckmann and von Benda-Beckmann 2007) or the effects of large scale, government sponsored transmigration programs as that of Indonesia (Murray Li 2007, p. 259; Sodhi et al. 2009; Rist et al. 2010). Concepts of "indigenous" space then often clash with the concept of citizenship in a young nation state where anyone can settle wherever they like (Murray Li 2007, pp. 114-116). What's more, displaced communities argue that their identities and associated rights should not be dependent on fixed associations with a certain territory, but should be portable (Murray Li 2007, p. 173).

A further problem with essentialised understandings of "indigenous and local communities" is that as legal classifications and categories they force communities to live up to the expectations of outsiders, especially of lawyers and administrators, with regards to the "authenticity" of their "traditional lifestyles". Such categories favour "tribal" over urban based knowledge and "indigenous" knowledge over tradition based forms of knowledge related to court cultures and elites, to a country's majority population or to migrant communities (Antons 2008, p. 295). All too often, villagers and forest dwellers who attempt to improve their situation are subsequently seen as no longer matching the expectations with regards to the authenticity of their "traditional lifestyles". Forsyth and Walker (2008, pp. 213-214) explain how in Thailand, "traditional" village life may become associated with lack of education, electricity or public health in the case of one Karen village, whereas another Karen village with road access and market integration is seen as already too "modernised".

Different from settler societies such as Australia, New Zealand, the United States and Canada, much of traditional knowledge in Asia may also reside in fairly large majority population groups or even at the national level. Examples from traditional medicine are Indian Ayurveda, Chinese or Thai traditional medicine and Indonesian jamu, which is originally associated with the main island of Java, but has meanwhile become a term of the national language Bahasa Indonesia referring to Indonesian traditional medicine more generally (Antons 2005; Antons and Antons-Sutanto 2009).

As a consequence, many Asian governments for many years have expressed reservations about the applicability of the term "indigenous people" in Asia, a concept which in their views was more appropriately used in connection with the situation in AngloAmerican settler colonies (Kingsbury 1999; Persoon 2009; Benjamin 2002, pp. 14-15; Murray Li 2000). The difference came to expression during the deliberations in the WIPO IGC about a voluntary fund established to support the participation of accredited local and indigenous communities in the IGC debates (Antons 2007, pp. 5-6). The Indian Delegation, for example, pointed out that "indigenous and local communities" were "terms that had a connotation derived from the colonial era when an attempt was made to distinct between colonists and the original people inhabiting a particular country" (WIPO 2005, p. 30). The Delegation of Indonesia concluded that "the tendency of the present use of the term originated in a colonial context, in which the ruling majority of colonialists had to be differentiated from the so-called original people living on the land before the colonialists came." The Indonesian delegation proposed instead to use terms such as "traditional community" or "traditional society" or "society or community bound by customary law" (WIPO 2005, pp. 26-27). In spite of such reservations, Southeast Asian countries voted in favour of the UN Declaration on the Rights of Indigenous Peoples in 2007. Statements of 
government representatives explaining the vote remained somewhat ambiguous, however (Antons 2009c). The Indonesian representative proceeded on the basis of the definition used in the International Labour Organization Convention No. 107 concerning the Protection and Integration of Indigenous, and other Tribal and Semi-tribal populations in Independent Countries of 1957 "according to which indigenous people were distinct from tribal people. Given the fact that Indonesia's entire population at the time of colonization remained unchanged, the rights in the declaration accorded exclusively to indigenous people and did not apply in the context of Indonesia" (UN General Assembly 2007, p. 13).

\section{The revival of customary law in community based environmental governance related to traditional knowledge}

The problems with the identification of beneficiaries mentioned above equally put into question the easy applicability of customary law, another tool considered for community oriented, "bottom up" approaches to environmental governance (Ørebech et al. 2005). This revival of customary laws in many countries has come with decentralisation, a central pillar for many years of the 'good governance' mantra of the World Bank, donors, aid agencies and NGOs (von Benda-Beckmann and von Benda-Beckmann 2007). Attention has been paid to it during the drafting of new constitutions in the wake of the democratisation movement of the last few years. The development in Indonesia has been the most dramatic in the region and the country has moved from a centralised structure focused on Jakarta to a decentralised one, where considerable decision making and tax collecting powers have been transferred to what is collectively called "regional government", consisting of provinces, regencies and municipalities (Article 18 of the Indonesian Constitution of 1945). The "indigenous and local communities" as holders of traditional knowledge under the CBD are recognised in Indonesia as "customary law communities". Adat, the Indonesian term stemming from Arabic and usually translated as "custom" or "tradition" (Echols and Shadily 2000) has originally a wider meaning covering both the supernatural and secular social reality. The Dutch colonial government treated and developed it as a legal system and it has since been used to refer to forms which are enforceable and have legal consequences (von Benda-Beckmann 1979, pp. 113-118). Article 18B of the revised Indonesian Constitution of 1945 now "recognises and respects" such customary law communities and their rights "as long as these remain in existence and are in accordance with the societal development and the principles of the Unitary State of the Republic of Indonesia". A similar recognition of "the cultural identities and rights of traditional communities" follows from Article 28I in the new Chapter XA on Human Rights, which requires these to be "respected" with the somewhat ambiguously worded qualification that this has to happen "in accordance with contemporary development and civilisation" (Antons 2005, p. 40).

A similar balancing of respect for community customs and traditions, on the one hand, and national development objectives and environmental policies on the other hand, is visible from the Constitution of Thailand of 2007, which provides in Section 66 that a "community, local community or traditional community shall have the right to conserve or restore their customs, local wisdom, arts or good culture of their community and of the nation and participate in management, maintenance and exploitation of natural resources, the environment and biological diversity in a balanced and sustainable fashion." This balancing exercise comes finally also to expression in Article II Section 22 of the 1987 Constitution of the Republic of the Philippines according to which the state "recognizes 
and promotes the rights of indigenous cultural communities within the framework of national unity and development." Article XII Section 5 further provides that the state shall protect the rights of indigenous cultural communities "subject to the provisions of the Constitution and national development policies and programs" and that "the congress may provide for the applicability of customary laws governing property rights or relations in determining the ownership and extent of ancestral domain." Indigenous learning systems, arts, cultures and institutions are given recognition in various sections of Article XIV dealing with education, science and technology, arts, culture and sports.

The renewed interest in customary law for purposes of environmental governance is also linked to debates about a need to go beyond strict distinctions of public and private law through the recognition of intermediate forms such as "limited common property" that works exclusively towards outsiders, but treats resources as commons for insiders (Rose 1998). Such mixed forms of property may be easier to accommodate via the flexibility of customary law systems. Nevertheless, analysts have dampened the expectations regarding customary law in environmental governance and biodiversity protection a little. First, ever since decolonisation, Asian governments have viewed the customary laws of their populations with mixed feelings (Antons 2003). They symbolise a link to ancient traditions and are important symbols for national identity, but they are also suspect because of their potential to harbour pre-modern, sectarian and even secessionist tendencies. The constitutional provisions quoted above clearly show that in most cases, the rules of customary law are subordinated and made subject to the overriding imperatives of national development policies (Antons 2009b, p. 50). Secondly, it has been pointed out that colonisation, state building and globalisation have affected customary "traditions" in many parts of the world to such an extent that they have to be rebuilt and become discursive weapons in negotiation processes rather than statements about the regularity of past practices (Chanock 2009; Zerner 1994). Chanock (2005) sees some prospects for combining what he calls "new custom" and contracts, but fears that radically divergent interests of resource users will make such compromises difficult.

\section{Traditional knowledge and access to biodiversity: The example of Indonesia}

Indonesia provides an example of how many of these complex issues play out at the national level. The Indonesian government has recently been involved in various disputes with Malaysia over cultural heritage and traditional cultural expressions in the form of songs, handicrafts and dances (Antons 2009c; Gelling 2009). Traditional knowledge related to biodiversity, agriculture and traditional medicine has equally been the subject of crossborder disputes and "biopiracy" claims. Widely reported in the media (Antons and AntonsSutanto 2009, pp. 382-383) were the patenting of Eurycoma longifolia, widely used in traditional medicine and known in Malaysia as Tongkat Ali and in Indonesia as Pasak Bumi (GRAIN and Kalpavriksh 2006); aborted attempts by a Japanese cosmetics manufacturer to patent compounds of traditional Indonesian medicinal plants (GRAIN 2008); the prosecution of a farmer from East Java under Law No. 12 of 1992 on Plant Cultivation Systems for selling non-certified seeds to neighbours (Jhamtani and Patria 2006); and longstanding claims about the patenting in the US of a traditional Indonesian formula for making a special type of soya bean cake (tempe) (Sardjono 2006, pp. 204-205). As in many other Asian developing countries, the role of the national government of Indonesia in the conservation and exploitation of natural resources remains strong. This strong position is enshrined in Article 33(3) of the Constitution, which provides that "the land, the waters and the natural resources within 
are controlled by the State and shall be used for the greatest possible welfare of the people." It comes further to expression in two laws enacted by the Suharto government during the 1990s, Law No. 12 of 1992 on the Plant Cultivation System and Government Regulation No. 44 of 1995 on Plant Germination. Law No. 12/1992 foresees that the government undertakes the search for and collection of genetic resources for the purpose of plant breeding and may license individuals or corporate bodies to undertake this task (Article 9(2), (3)). Bioprospectors and collectors that act without licence are facing jail terms and fines (Article 60). Conservation of genetic resources is the task of government and society together (Article 9(4)). Government Regulation No. 44/1995 equally provides that genetic resources are controlled by the government and used for the greatest possible welfare of the people (Article 3). Again, the government is generally in charge of the search for, collection, use and conservation of plant genetic resources, but Indonesian citizens or corporate bodies may be licensed for search and collection (Article 5(1), (2)). Search and collection of genetic resources is only allowed for the purposes of plant breeding and may be undertaken by foreign parties only in the context of research collaboration with an Indonesian counterpart (Article 5(3), (4)). Export of genetic resources is only allowed for specified species and for research purposes in plant breeding, whereby an exchange of such resources is envisaged (Article 14).

Access of foreigners and foreign institutions depends, therefore, on research permits and their content. For these purposes, an initial Presidential Decision was issued in 1993 (No. 100/1993) followed by implementing regulations in a Circular letter of the Head of the Indonesian Science Agency (LIPI) in 1998. Under this scheme, LIPI prepared and provided Material Transfer Agreements (MTAs) to be signed by the foreign researchers and their Indonesian partners (Subroto and Suprapedi 2001; Antons 2009b, pp. 56-57). These various regulations have been replaced by Government Regulation No. 41 of 2006, which now regulates the granting of official permits for foreign researchers by the Ministry for Research and Technology. Article 20(2) of this Regulation prohibits foreign researchers in general to take samples or specimens related to their research outside of Indonesia, unless this is allowed by a further regulation. The official government memorandum to this provision explains that the further regulation referred to is Law No. 4 of 2006 on the Ratification of the International Treaty on Plant Genetic Resources for Food and Agriculture (ITPGR), to which Indonesia acceded in 2006, and the ITPGR's Material Transfer Agreement.

Where a bioprospecting activity concerns forest products, it may be necessary to obtain further permits from the forestry departments. Law No. 41 of 1999 on Forests distinguishes in Article 1 between state, private and production forests, "forests under customary law" (hutan adat) and various types of protected and conservation forests. The Law provides nevertheless in Article 2(1) that all forests and natural resources are controlled by the government. The rights of communities under customary law are to be respected, however, "as long as there is evidence that they still exist, their existence is still acknowledged and not in conflict with the national interest" (Article 2(3)). Regional authorities are empowered to make the decision about the existence or otherwise of a customary law community via a Regional Regulation (Article 67(2)). If its existence is acknowledged, then the community is allowed to collect forest products for subsistence, manage the forest in accordance with customary law that must not conflict with state law and "become empowered within a framework of raising its prosperity" (Article 67(1)). The recognition by the central government of a forest under customary law depends on this prior acknowledgment as customary law community by the regional authorities (Article 5(3)). If the customary law community ceases to exist, the central government takes over the 
management of this forest (Article 5(4)). A further Government Regulation of 2002 and a Regulation of the Minister of Forestry of 2008 contain further provisions and partly overlapping responsibilities of central government and regional authorities for exploitation permits in various types of forests (Antons 2009b, pp. 57-58).

Traditional knowledge does not feature in these various laws. Fleeting reference to it is made with regards to farmers in the preamble to the ITPGR Ratification Law No. 4/2006 and more generally in the preamble to Law No. 5 of 1994 on the Ratification of the United Nations Convention on Biological Diversity. Significantly, however, it is not listed among the benefits of the CBD for Indonesia outlined in the explanatory memorandum to Law No. 5/1994. In its Fourth National Report on the implementation of the CBD submitted in September 2009, Indonesia admitted that the targets of protecting traditional knowledge, innovations and practices as well as the rights of indigenous and local communities over such knowledge, innovations and practices had not yet been completely achieved. The report mentioned draft regulations to protect traditional knowledge and practices, "some rules at local levels" and a database of traditional knowledge. It also mentioned benefit sharing with local communities put into effect by the Plant Variety Protection Office (Government of Indonesia 2009, p. 64).

The latter statement refers to Indonesia's Law No. 29 of 2000 on Plant Variety Protection. Article 7(1) of this Law provides that "local varieties owned by communities are controlled by the state" (Antons 2009b, p. 58). Article 7(4) explains that the government will regulate further details, which according to the explanatory memorandum to the provision include the economic benefits for the local community that owns the variety. This benefit sharing is now becoming implemented according to the government's report to the CBD. Law No. 29 of 2000, however, covers only plant breeding and does not regulate benefit sharing related to other activities.

Traditional knowledge databases have been compiled by various Ministries in Indonesia since several years (Antons 2009c). This development has been accelerated after the various disputes between Indonesia and Malaysia over traditional cultural expressions and forms of traditional knowledge (Ministry of Culture and Tourism 2009; Antons 2009d, p. 114). Finally, the draft specialised law on traditional knowledge mentioned in the most recent report to the CBD has in fact been under discussion since 2001, but is now expected to be finalised and submitted to the Indonesian parliament in 2010 (Waspada Online 2009). Among other things, this new sui generis legislation will cover intellectual property protection for various forms of traditional knowledge and the sharing of benefits between knowledge holders and users. Press reports indicate that, at least at this stage, much of the financial benefits are supposed to go to regional government institutions with an important role to be played by customary law councils (dewan adat). Where such councils do not exist, the benefits are expected to flow to the regional government and to the national government, if the traditional knowledge is held by people in various provinces (Republika Online 2008; Ryadi 2008).

\section{Conclusion}

The example of Indonesia and the difficult balancing acts with regards to traditional knowledge, customary law and local communities in other Southeast Asian countries show that regional governments on average have found it difficult to implement the community based model of environmental governance envisaged in the CBD and in other international agreements. A partial exception here is the Philippines, where there is a tradition of 
recognising "indigenous peoples" ever since the US American colonial government established a Bureau of Non-Christian Tribes modelled after the administration of North American Indians (Eder and McKenna 2004, pp. 60-61). However, in many parts of Southeast Asia, widespread displacement and migration has made it difficult to clearly establish the right holders and beneficiaries of the new governance models and newly established rights to forms of traditional knowledge. Many forms of tradition are also practised by the population at large and not restricted to minorities. This fact and the parts of the CBD that allow for national control of resources and commercialisation have led to a situation where the distinction between the rights and interests of local communities, regions and the nation state becomes blurred. Although local communities are at the centre of the new environmental governance paradigms, their role is often symbolic. Of the various incentives under discussion to encourage biodiversity conservation, intellectual property based models are perhaps the most complicated. While communities benefit from equitable benefit-sharing and compensation schemes, their position remains fragile and their interests subordinated to national development goals. If this leads to a concentration on royalty collection by various regional and central administrations, then it is important that such benefits are passed on and that governments move beyond mere national development goals, so that communities at the grassroots level see sufficient incentives to uphold practices regarded as important for conservation (Sodhi et al. 2009). With national governments defending indigenous knowledge and heritage, regional disputes over such traditions have also emerged, showing that in this area as well international cooperation in policy making is required and national efforts alone are insufficient (Woodruff 2010). The solution of these disputes requires, therefore, ASEAN wide regional mechanisms and approaches as envisaged in the Draft ASEAN Framework Agreement on Access to Biological and Genetic Resources.

Open Access This article is distributed under the terms of the Creative Commons Attribution Noncommercial License which permits any noncommercial use, distribution, and reproduction in any medium, provided the original author(s) and source are credited.

\section{References}

Antons C (2003) Legal culture and history of law in Asia. In: Heath C (ed) Intellectual property law in Asia. Kluwer Law International, London, pp 13-35

Antons C (2005) Traditional knowledge and intellectual property rights in Australia and Southeast Asia. In: Heath C, Kamperman Sanders A (eds) New frontiers of intellectual property law-IP and cultural heritage, geographical indications, enforcement and overprotection. Hart Publishing, Oxford, Portland, pp 37-51

Antons C (2007) Traditional knowledge, biological resources and intellectual property rights in Asia: the example of the Philippines. In: Forum of International Development Studies 34 (March 2007), pp 1-18

Antons C (2008) Traditional cultural expressions and their significance for development in a digital environment: examples from Australia and Southeast Asia. In: Graber CB, Burri-Nenova M (eds) Intellectual property and traditional cultural expressions in a digital environment. Edward Elgar, Cheltenham, Northampton, pp 287-301

Antons C (2009a) Introduction. In: Antons C (ed) Traditional knowledge, traditional cultural expressions and intellectual property law in the Asia-Pacific Region. Kluwer Law International, Alphen aan den Rijn, pp 1-36

Antons C (2009b) The international debate about traditional knowledge and approaches in the Asia-Pacific Region. In: Antons C (ed) Traditional knowledge, traditional cultural expressions and intellectual property law in the Asia-Pacific region. Kluwer Law International, Alphen aan den Rijn, pp 39-65

Antons C (2009c) Traditional knowledge in Asia: global agendas and local subjects. In: Gillespie J, Peerenboom R (eds) Regulation in Asia. Routledge, London, pp 64-84 
Antons C (2009d) What is "traditional cultural expression"? International definitions and their application in developing Asia. WIPO J 1:103-116

Antons C, Antons-Sutanto R (2009) Traditional medicine and intellectual property rights: a case study of the Indonesian Jamu Industry. In: Antons C (ed) Traditional knowledge, traditional cultural expressions and intellectual property law in the Asia-Pacific region. Kluwer Law International, Alphen aan den Rijn, pp 363-384

Asia Sentinel (2009) India ignores global warming. 3 September 2009

Beers SJ (2001) Jamu: the ancient Indonesian art of herbal healing. Periplus Editions (HK) Ltd, Hong Kong

Benjamin G (2002) On being tribal in the Malay world. In: Benjamin G, Chou C (eds) Tribal communities in the Malay world: historical, cultural and social perspectives. Institute of Southeast Asian Studies and International Institute for Asian Studies, Singapore, Leiden, pp 7-76

Biber-Klemm S, Szymura Berglas D (2006) Problems and goals. In: Biber-Klemm S, Cottier T (eds) Rights to plant genetic resources and traditional knowledge: basic issues and perspectives. CABI, Oxfordshire, Cambridge, pp 3-55

Biber-Klemm S, Cottier T, Cullet P, Szymura Berglas D (2006) The current law of plant genetic resources and traditional knowledge. In: Biber-Klemm S, Cottier T (eds) Rights to plant genetic resources and traditional knowledge: basic issues and perspectives. CABI, Oxfordshire, Cambridge, pp 56-111

Brush SB (2005) Protecting traditional agricultural knowledge. Wash Univ J Law Policy 17:59-109

Burnett V (2009) UN chief warns of food shortages in poor countries. International Herald Tribune, 27 January 2009

Chanock M (2005) Customary law, sustainable development and the failing state. In: Ørebech P, Bosselman F, Bjarup J, Callies D, Chanock M, Petersen H (eds) The role of customary law in sustainable development. Cambridge University Press, Cambridge, pp 338-383

Chanock M (2009) Branding identity and copyrighting culture: orientations towards the customary in traditional knowledge discourse. In: Antons C (ed) Traditional knowledge, traditional cultural expressions and intellectual property law in the Asia-Pacific region. Kluwer Law International, Alphen aan den Rijn, pp 177-193

Correa C M (2000) Options for the implementation of farmers rights at the national level. Trade-related agenda, development and equity (T.R.A.D.E.) Working Papers, No. 8, Geneva, 2000

Echols JM, Shadily H (2000) Kamus Indonesia Inggris: an Indonesian-English dictionary. PT Gramedia, Jakarta

Eder JF, McKenna TM (2004) Minorities in the Philippines: ancestral lands in theory and practice. In: Duncan CR (ed) Civilizing the margins: Southeast Asian Government Policies for the development of minorities. Cornell University Press, Ithaca, London, pp 56-85

Erdelen WR, Adimihardja K, Moesdarsono H, Sidik (1999) Biodiversity, traditional medicine and the sustainable use of indigenous medicinal plants in Indonesia. In: Indigenous Knowledge and Development Monitor, November 1999, http://www.nuffic.nl/ciran/ikdm/7-3/erdelen.html. Accessed 13 November 2006

Flitner M (1998) Biodiversity: of local commons and global commodities. In: Goldman M (ed) Privatizing nature: political struggles for the global commons. Pluto Press, London, pp 144-166

Forsyth T, Walker A (2008) Forest guardians, forest destroyers: the politics of environmental knowledge in Northern Thailand. Silkworm Books, Chiang Mai

Gelling P (2009) Score One for Indonesia in the War Over Batik. The New York Times, September 15, 2009

Gervais D (2003) The TRIPS agreement: drafting history and analysis, 2nd edn. Sweet \& Maxwell, London

Goldman M (1998) Introduction: the political resurgence of the commons. In: Goldman M (ed) Privatizing nature: political struggles for the global commons. Pluto Press, London, pp 1-19

Government of Indonesia (2009) Fourth national report-convention on biological diversity, 2009. http:// www.cbd.int/doc/world/id/id-nr-04-en.pdf. Accessed 16 September 2009

GRAIN (2008) Japan digs its claws into biodiversity through FTAs. (August 2007), http://www.grain. org/articles/?id=29. Accessed 12 August 2008

GRAIN, Kalpavriksh (2006) Traditional knowledge of biodiversity in Asia-Pacific: problems of piracy \& protection. http://www.grain.org/briefings/?id=97. Accessed 13 October 2006

Jhamtani H, Patria D (2006) Case documentation: Indonesian farmers prosecuted for breeding their own seeds. 20 October 2006, http://asianfarmers.org/?p=208. Accessed on 22 March 2007

Kingsbury B (1999) The applicability of the international legal concept of "indigenous peoples" in Asia. In: Bauer JR, Bell DA (eds) The East Asian challenge for human rights. Cambridge University Press, Cambridge, pp 336-377

Ministry of Culture and Tourism (2009) Menbudpar Kembali Ingatkan Agar Karya Budaya Didaftarkan. 25 August 2009, http://www.budpar.go.id/page.php?ic=511\&id=5077. Accessed 30 August 2009 
Murray Li T (2000) Locating indigenous environmental knowledge in Indonesia. In: Ellen R, Parkes P, Bicker A (eds) Indigenous environmental knowledge and its transformations: critical anthropological perspectives. Routledge, London, pp 121-149

Murray Li T (2007) The will to improve: governmentality, development, and the practice of politics. Duke University Press, Durham, London

Newell P (2008) The marketization of global environmental governance: manifestations and implications. In: Park J, Conca K, Finger M (eds) The crisis of global environmental governance: towards a new political economy of sustainability. Routledge, Oxford, New York

Ørebech P, Bosselman F, Bjarup J, Callies D, Chanock M, Petersen H (2005) The role of customary law in sustainable development. Cambridge University Press, Cambridge

Persoon GA (2009) 'Being indigenous' in Indonesia and the Philippines. In: Antons C (ed) Traditional knowledge, traditional cultural expressions and intellectual property law in the Asia-Pacific region. Kluwer Law International, Alphen aan den Rijn, pp 195-216

Republika Online (2008) Hak Cipta dan Paten Budaya Diatur dalam UU Baru. 2 December 2008, http://www.republika.co.id/print/17772. Accessed 30 August 2009

Rimmer M (2008) Intellectual property and biotechnology: biological inventions. Edward Elgar, Cheltenham, Northampton

Rist L, Feintrenie L, Levang P (2010) The livelihood impacts of oil palm: smallholders in Indonesia. Biodivers Conserv. doi:10.1007/s10531-010-9815-z

Rose CM (1998) The several futures of property: of cyberspace and folk tales, emission trades and ecosystems. Minn Law Rev 83:129-182

Ryadi TA (2008) Lindungi Pengetahuan dan Ekspresi Budaya Bangsa. In: Jurnal Nasional, 3 December 2008, http://www.forumbudaya.org/index.php?option=com_content\&task=view\&id=228\&itemid=61. Accessed 30 August 2009

Sagar R (2005) Intellectual property, benefit-sharing and traditional knowledge: how effective is the Indian Biological Diversity Act, 2002? J World Intellect Prop 8(3):383-400

Sardjono A (2006) Hak kekayaan intelektual dan pengetahuan tradisional. Penerbit P.T. Alumni, Bandung

Sissons J (2005) First peoples: indigenous culture and their futures. Reaktion Books, London

Sodhi NS, Lee TM, Sekercioglu CH, Webb EL, Prawiradilaga DM, Lohman DJ, Pierce NE, Diesmos AC, Rao M, Ehrlich PR (2009) Local people value environmental services provided by forested parks. Biodivers Conserv. doi:10.1007/s10531-009-9745-9

Straus J (2008) How to break the deadlock preventing a fair and rational use of biodiversity. J World Intellect Prop 11(4):229-295

Subroto MA, Suprapedi (2001) Aspek-aspek kekayaan intelektual dalam penyusunan perjanjian penelitian dengan pihak asing di bidang biologi. Paper presented at the 'Rapat Tim Koordinasi Pemberian Ijin Penelitian', Lembaga Ilmu Pengetahuan Indonesia (LIPI), 16 October 2001, available at http://www.haki.lipi.go.id. Accessed 4 April 2006

Tay SSC, Esty DC (1996) Introduction: trade and the environment-context and controversy. In: Tay SSC, Esty DC (eds) Asian dragons and green trade: environment, economics and international law. Times Academic Press, Singapore, pp 1-18

United Nations General Assembly (2007) General assembly adopts declaration on rights of indigenous peoples. GA 10612 of 13 September 2007, http://www.un.org/News/Press/docs//2007/ga10612.doc. htm. Accessed 30 October 2007

von Benda-Beckmann F (1979) Property in social continuity: continuity and change in the maintenance of property relationships through time in Minangkabau, West Sumatra. Martinus Nijhoff, The Hague

von Benda-Beckmann F, von Benda-Beckmann K (2007) Between global forces and local politics: decentralisation and reorganisation of village government in Indonesia. In: Antons C, Gessner V (eds) Globalisation and resistance: law reform in Asia since the crisis. Hart Publishing, Oxford, Portland, pp 211-252

Waspada Online (2009) Surat Malaysia diperkirakan pekan depan. 28 August 2009, http://www.waspada. co.id/index.php?view=article \&catid=17\%3Anasional\&id=48312. Accessed 30 August 2009

Wheatley A (2008) High food prices sound an alarm across Asia. International Herald Tribune, 21 January 2008

Wilcove DS, Koh LP (2010) Addressing the threats to biodiversity from oil-palm agriculture. Biodivers Conserv. doi:10.1007/s10531-009-9760-X

WIPO (2003) Intergovernmental committee on intellectual property and genetic resources, traditional knowledge and folklore, sixth session, Geneva, December 12, 2003, traditional knowledge: policy and legal options, WIPO/GRTKF/IC/6/4 of 12 December 2003

WIPO (2005) Intergovernmental committee on intellectual property and genetic resources, traditional knowledge and folklore, eighth session, Geneva, June 6-10, 2005, second draft report, WIPO/GRTKF/ IC/8/15 Prov. 2 of 5 October 2005 
WIPO (2006) Intergovernmental committee on intellectual property and genetic resources, traditional knowledge and folklore, ninth session, Geneva, April 24 to 26, 2006, The protection of traditional knowledge: revised outline of policy options and legal mechanisms, WIPO/GRTKF/IC/9/INF/5 of 27 March 2006

WIPO (2007) Intergovernmental committee on intellectual property and genetic resources, traditional knowledge and folklore, the protection of traditional knowledge: revised objectives and principles, WIPO/GRTKF/IC/12/5(c) of 6 December 2007

WIPO (2008) Intergovernmental committee on intellectual property and genetic resources, traditional knowledge and folklore, thirteenth session, Geneva, October 13-17, 2008, genetic resources: factual update of international developments. WIPO/GRTKF/IC/13/8(b) of September 8, 2008

WIPO (2009a) Intergovernmental committee on intellectual property and genetic resources, traditional knowledge and folklore, fourteenth session, Geneva, June 29 to July 3, 2009, initial draft report. WIPO/ GRTKF/IC/14/12 Prov. of July 31, 2009

WIPO (2009b) WIPO assemblies provide direction for next biennium. http://wipo.int/portal/en/news/2009/ article_0038.html. Accessed 19 October 2009

Woodruff D (2010) Biogeography and conservation in Southeast Asia: how 2.7 million years of repeated environmental fluctuations affect today's patterns and the future of the remaining refugial-phase biodiversity. Biodivers Conserv. doi:10.1007/s10531-010-9783-3

Zerner C (1994) Through a green lens: the construction of customary environmental law and community in Indonesia’s Maluku Islands. Law Soc Rev 28(5):1079-1122 